\title{
On the Utopian Possibility in Ursula K. Le Guin's The Dispossessed: A Lacanian Reading
}

\author{
Res. Assist. Murat Kabak \\ Istanbul Kültür University, Faculty of Science and Letters \\ Department of English Language and Literature \\ m.kabak@iku.edu.tr
}

\begin{abstract}
Written in 1974, the American writer Ursula K. Le Guin's The Dispossessed revolves around the central character Shevek's self-appointed mission to improve the relationship between two planets, Anarres and Urras, by breaking down the walls that are separating these ideological enemies. The novel, in that sense, can be read as one man's search for an ideal state, rather than a description of a utopian/anti-utopian state. Literary scholars generally focus on various aspects of The Dispossessed in terms of its anarchist politics, ecological politics, and revolutionary politics. This article; however, aims to approach the novel from a Lacanian perspective by addressing the protagonist's psyche and his relation to the socio-symbolic orders in the novel. By focusing on the characterization of the relations between the subject and the other in an anarchist (as well as a capitalist culture) in The Dispossessed, this article aims to analyze how the novel provides a path towards an ideal state.
\end{abstract}

Keywords: Lacanian psychoanalysis, The Dispossessed, Ursula K. Le Guin, utopian tradition.

\section{Ursula K. Le Guin'in Mülksüzler Romanında Ütopyacı İhtimal Üstüne Bir Lacancı Okuma}

Öz

Amerikalı yazar Ursula K. Le Guin'in 1974'te yazdığı Mülksüzler romanı, ana karakter Shevek'in Anarres ve Urras isimli iki gezegenin ilişkilerini, bu ideolojik düşmanları ayıran sembolik duvarları yıkarak geliştirmek için çıktığı görevi konu alır. Roman, bu anlamda, ütopik/anti-ütopik bir devlet tasvirinden çok, tek bir adamın ideal bir devlet arayışı olarak okunabilir. Eleştirmen ve akademisyenler, Mülksüzler romanını çoğunlukla anarşist, ekolojik ve devrimci siyaset açısından çeşitli yönleriyle ele almıştır. Ancak bu makale, kahramanın psikolojisine ve bunun romandaki sosyo-sembolik düzenlerle ilişkisine değinerek romana Lacancı bir bakış açısıyla yaklaşmayı amaçlamaktadır. Bu makale, Mülksüzler romanında özne ile öteki arasındaki ilişkileri anarşist (ve aynı zamanda kapitalist) bir kültürde nasıl nitelendirebileceğimize odaklanarak, romanın ideal bir topluma doğru nasıl bir yol sağladığını incelemeyi amaçlamaktadır.

Anahtar Kelimeler: : Lacancı psikanaliz, Mülksüzler, Ursula K. Le Guin, ütopya geleneği.

Sending Date / Gönderim Tarihi: 26/08/2020 Acceptance Date / Kabul Tarihi: 09/11/2020 


\section{INTRODUCTION}

A crisis of consciousness coincides with political crisis in Ursula K. Le Guin's The Dispossessed: An Ambiguous Utopia. Written in 1974, the novel revolves around the central character Shevek's self-appointed mission to improve the relationship between two planets, Anarres and Urras, by breaking down the walls that are separating these ideological enemies. The novel, in that sense, can be read as one man's search for an ideal state, rather than a description of a utopian/anti-utopian state. Considering that the novel was written shortly after the protests of 1968, a period that was defined by the rise of various emancipatory ideologies such as Marxism, anarchism, and feminism, and the novel's explicit preoccupation with two political organizations (anarchism represented in Anarres, and capitalism embodied in Urras), it should not come as a surprise to us that a majority of literature written on The Dispossessed focuses on its political aspect.

As a key text in the history of science fiction, The Dispossessed has been considered from various critical perspectives. While it would be impossible to give an account of the entire critical reception of the novel, literary scholars generally analyzed the novel in terms of its anarchist politics, ecological politics, and revolutionary politics. Peter G. Stillman (2005), for instance, focuses on the environmental and ecological concerns in the novel arguing that Anarres functions as a thought experiment to "establish and maintain a society of liberty, equality, and community despite severe shortages of resources" (p. 56). In that sense, the fictional anarchist society Anarres provides a blueprint for an ecological utopia for the reader ${ }^{1}$. In a similar manner, Bülent Somay (2005) focuses on the revolutionary politics of The Dispossessed, and argues that the novel provides the reader with the exemplary revolutionary figure of Shevek, who is always in the process of "self-deconstruct[ion] and self-reconstruct[ion] at the same time" (p. 244) and posits the utopia at the end of the novel in the future. While more contemporary critics have championed Le Guin's novel for its emancipatory politics, earlier critics such as Nadia Khouri (1980) holds the opposite view by arguing that the novel is "regressive", "moralistic" and "reductionist" (p. 50). Khouri argues that Le Guin fails to "dramatize the relationship between power and the utopian possibility" (1980, p. 50) and contends that the novel reduces "the dialectic to binary oppositions" (1980, p. 51), such as associating scarcity, brotherhood and equality with Anarres, while equating abundance, competition and inequality with Urras.

Reading the novel from a Lacanian perspective, this article aims to address what is largely missing in the secondary literature, that is the protagonist's psyche and his relation to the socio-symbolic orders in the novel. Because while a political or ecocritical perspective would put the protagonist's transformation through his journey from one social structure to another, a Lacanian reading would foreground the character development instead of a mere political analysis. By focusing on the characterization of the relations between the subject and the other in an anarchist (as well as a capitalist culture) in The Dispossessed, this article aims to approach the novel from a Lacanian perspective, and to answer two questions at the same time, while not prioritizing one over the other: First, what would a Lacanian approach to the novel contribute to our understanding of its revolutionary politics? And second, if the novel provides a path towards an ideal state, what is Le Guin's utopian vision? I argue that

\footnotetext{
${ }^{1}$ See also Sabia, D. (2005) and Tunick, M. (2005) in L. Davis, \& P. G. Stillman (Eds.), The New Utopian Politics of Ursula K. Le Guin's The Dispossessed, and Jaeckle, D. (2009). Embodied Anarchy in Ursula K. Le Guin's The Dispossessed. Utopian Studies, 20(1), 75-95.
} 
by assuming the discourse of the hysteric, which is a term in Lacanian psychoanalysis designating a subject position that always engages in questioning the dominant discourse, the protagonist, Shevek, undermines the stability of both the capitalist and the anarchist socio-symbolic orders. Unable to conform to the norms of his society, Shevek also fails to lead a revolution on the capitalist planet, Urras. Yet, his true revolutionary action comes at the end where he reverses the master's discourse, another term in the Lacanian discourse theory standing for the norms and ideas of the dominant group. A Lacanian analysis would inform us how Shevek develops as a character from the hysteric to the analyst and how this process informs the novel's utopian vision.

Before moving on to an analysis of the novel, a brief discussion of the theoretical framework is in order. The French psychiatrist Jacques Lacan argued that the human subject emerges through the discursive play of signifiers (1991/2007, p. 12), which are a part of what Lacan called the symbolic order. This marks the separation from the mother who is the infant's closest tie to the Real. Elaborating his discourse theory first in Seminar XVII (1991/2007), Lacan discerns four discourses: the master's discourse, the university discourse, the hysteric's discourse, and the analyst's discourse (pp. 92-93). In Seminar XX (1975/1999), Lacan contends that each discourse has the same structure, and consists of four positions: agent, other, truth, and product (see Fig. I). The upper part of the formula signifies the oneway relationship between the agent and the other, while the lower part shows the hidden side of each discourse which is (the hidden) truth and the product of the relationship between the agent and the other. The four symbols shown with algebraic symbols $\left(S_{1}, S_{2}, \$\right.$ and $a$ ) are the concepts that change positions in all four discourses. While $S_{1}$ designates the master signifier which always signifies itself (and not other signifiers), $S_{2}$ signifies "the symbolic knowledge [which] is the Other's jouissance" (1991/2007, p. 15). The symbol $a$ (the surplus jouissance) stands for the pleasure produced by the discourse (as in the master's discourse) and \$ symbolizes the divided subject.

Figure I: The four positions in the discourse theory and the terms

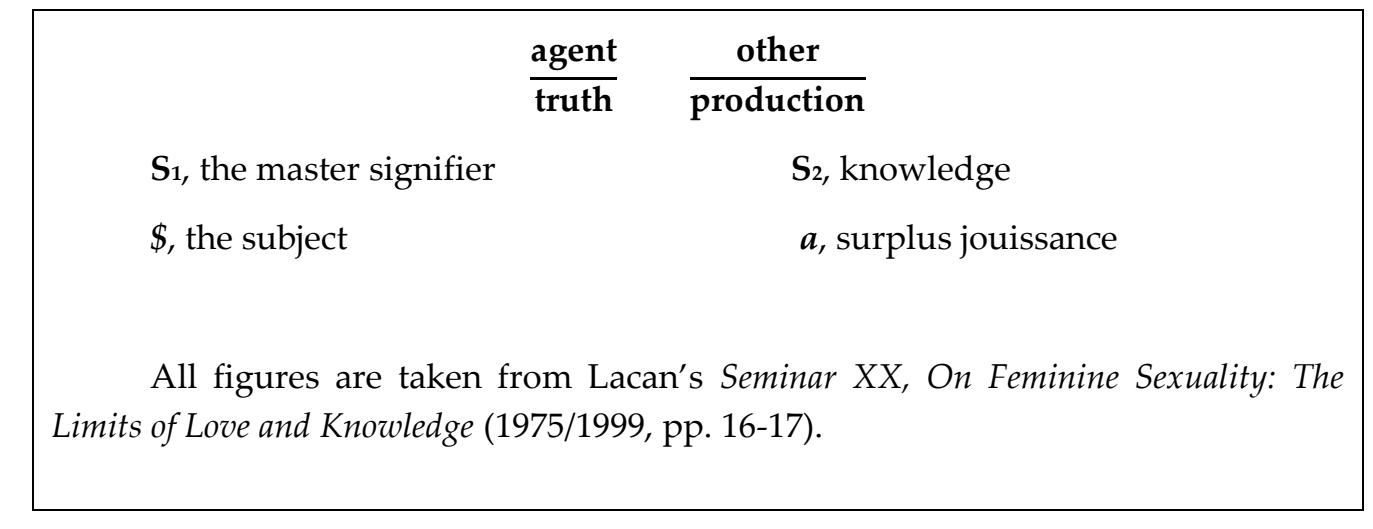

The importance of Lacan's formulation of discourses lies in its positioning the subject into a socio-symbolic order. These discourses do not correspond to fixed subject positions in Lacan's psychoanalysis. As Pietro Bianchi (2012) points out, discourse is etymologically derived from dis- 'apart' + currere 'to run' (p. 116), meaning that there is a constant change in places and relations regulating the social bonds in a social order. In that sense, Lacan's 
discourse theory allows the critic to follow the subject's fluid, continuously changing position in a given context by analyzing the subject's relationship to the other and the object cause of desire (or surplus jouissance, signified with $a$ in Lacan's works).

\section{Anarres: Anarchism and Its Discontents}

One hundred and seventy years before the opening of the novel, the members of a revolutionary group, led by an anarchist named Odo, have migrated to the neighbor planet Anarres (Le Guin, 1975, p. 71) to build an anarchist community on the principles of solidarity and mutual aid (Le Guin, 1975, p. 95). While Anarres is a decentralized, utopian community that seems to have eliminated all socio-economic inequalities, its binary opposite Urras remains a state-capitalistic social order. Shevek, a theoretical physicist, leaves Anarres as a political exile with the hope of introducing his theory called the General Temporal Theory to the Urrasti government (Le Guin, 1975, p. 72).

In "The Dispossessed as Ecological Political Theory", Stillman argues that from an ecocritical perspective, Anarres is the blueprint for an ideal state that does not have economic, interpersonal or institutionalized violence, or violence against nature (2005, pp. 60-61). Stillman argues that on Anarres, individuals "are not subjected to social practices (such as states) that generate violence, institutionalize it, and encourage its recurrence" (2005, p. 60). On Urras; however, there are state apparatuses that are used to oppress dissidents, as seen in Chapter 11. In that sense, Stillman contends that "what makes Anarres utopian is that violence, which does not occur, has been disconnected from institutionalized human structures and it limited, transitory, and specific to a single issue" $(2005$, p. 60). Yet, the shortcoming of an ecocritical approach is its inability to address Shevek's departure from the ecotopia, since the very fact that a member of the seemingly utopian community leaves it suggests that there is something inherently wrong in that utopia. It is not a question of whether Anarres is able to provide an eco-friendly and sustainable system or not. As also Stillman cites, the Anarresti were able to create a feasible and desirable economic structure despite the planet's harsh conditions. Acknowledging that Anarres is a sustainable sociosymbolic order, my question is how this social structure is made sustainable? I argue that what drives Shevek to a search of his own utopia is his alienation from his community which is dominated by the master's discourse.

Early in the novel, we see how Shevek's infantile narcissism is suppressed by the orthodox Odonian socio-symbolic order. The baby, unable to distinguish its own body from the outside world, perceives everything as its extension, while anarchist ideology is not compatible with this possession:

\footnotetext{
"Mine!" he said in a high, ringing voice. "Mine sun!"

"It is not yours," the one-eyed woman said with the mildness of utter certainty. "Nothing is yours. It is to use. It is to share. If you will not share it, you cannot use it". She picked the knobby baby up ... and set him aside, out of the square of sunlight ... He sobbed ... and hid his face in the darkness of the lost sun. (Le Guin, 1975, p. 22)
}

The suppression of the baby Shevek's narcissism continues to show its effects in his adult life. This view of limiting the infant's perception partly stems from the fabricated language of Anarres, Pravic. Specifically created for the purposes of Odonianism, Pravic does not allow the speaker to utter a sentence such as "my hand hurts". Instead, the speaking subject uses the expression "the hand hurts me" (Le Guin, 1975, p. 46). This aspect 
of the Pravic language is significant for its removal of the speaking subject from being the subject (in the grammatical sense) of his own sentence. The Slovenian philosopher Slavoj Žižek (2007) uses the metaphor of the Trojan horse to describe Lacan's view of the language's invasive role on the human psyche: "For Lacan, language is a gift as dangerous to humanity as the horse was to the Trojans: it offers itself to our use free of charge, but once we accept it, it colonizes us" (pp. 11-12). This colonization, for Lacan, marks the subject's delusion of being in control of his/her actions and thoughts. As Bruce Fink (1995) points out, "[f]rom the viewpoint of the self or ego, "I" runs the show: that aspect of us that we call "I" believes that it knows what it thinks and feels, and believes that it knows why it does what it does" (p. 4). However, in the fabricated language of Anarresti, Pravic, the formation of ego is shunned. Shevek, as any other subject in the Anarresti order, is dispossessed not only on a material but also on a psychic level. One example would be a scene early in the novel where Shevek discusses one of his ideas with his friends. He tries to explain, theoretically speaking, when one throws a rock at a tree, that rock cannot reach its destination (Le Guin, 1975, p. 23). This is a variation of Zeno's paradox about the impossibility of motion. Yet, instead of supporting his creative and intellectual endeavors, the principal accuses him of "egoizing" (Le Guin, 1975, p. 24), i.e. not sharing. "Egoinizing", repeated quite often in the novel for Shevek, is significant for the purposes of a Lacanian analysis since the aim of the Anarresti discourse is to destroy the ego.

Figure II: The Master's Discourse

$$
\frac{\mathrm{S}_{1}}{\$} \quad \frac{\mathrm{S}_{2}}{a}
$$

By denying the individual subject's autonomy and by dismissing their creative power as merely 'egoizing', the master discourse of the anarchic society creates its perfect workers. This is the conclusion we draw from Lacan's master's discourse (see Fig. II) where the master $\left(S_{1}\right)$ who holds the dominant position (agent) puts the slave $\left(S_{2}\right.$ in the position of other) to work to extract the product ( $a$ or the surplus jouissance). It is true that Shevek, like all the other members of the Anarresti community, must work like a slave under these conditions. Individuals do not have the option to refuse job postings sent by an organization called the Production and Distribution Coordination (PDC), which coordinates syndicates and individuals (Le Guin, 1975, p. 61). In that sense, the society is built upon the tenets of solidarity and freedom of choice, but the latter is sacrificed for the sake of running the production smoothly. Shevek, even though he is a theoretical physicist, is often posted and reposted to different manual jobs, which would eventually lead to the separation from his partner and his child: "His eyes filled with tears of anger. A rage of disappointment shook him, a wrath, a foreboding ... [H]e had given up his book, and his love, and his child. How much can a man be asked to give up?" (Le Guin, 1975, p. 208). What we see in Shevek's questioning is his persistence in laying claim on "his book, his love, and his child", which is strictly forbidden by the master's discourse.

SEFAD, 2021; (45): 177-190 
Figure IV: The Hysteric's Discourse

\begin{tabular}{|ll|}
\hline$\frac{\mathrm{S}_{1}}{a}$ & $\frac{\mathrm{S}_{2}}{}$ \\
\hline
\end{tabular}

Shevek is rather aligned with the hysteric's discourse (see Fig. IV) which puts the master into question. He stands for the agent who questions the master signifier $\left(S_{1}\right)$ to reach knowledge, which is the product of his search (savoir or the symbolic knowledge shown as $S_{2}$ ). The physical product that Shevek is trying to produce in the novel is his temporal theory. If this 'product' is in the position of $S_{2}$ in Lacan's discourse theory, then what Shevek is trying to achieve is to be acknowledged for his efforts. As Lacan argues in his 1969 seminar, "symbolic knowledge is the Other's jouissance" (1991/2007, p. 15), meaning the knowledge is associated with the Other's object cause of desire (signified as $a$ ). Yet, under the conditions of the master's discourse which denies the subject's creative power, the more Shevek strives, the greater he fails. His attempts at being desired by the Other always ends in failure:

Three years here, and he had accomplished what? A book, appropriated by Sabul; five or six unpublished papers.

Nothing he did was understood. To put it more honestly, nothing he did was meaningful. He was fulfilling no necessary function, personal or social ... He would achieve nothing further. He had come up against the wall for good (Le Guin, 1975, pp. 130-131)

Unable to produce, even worse, unable to find the drive to produce, Shevek is completely alienated from his society. In this context, his questioning of the master signifier leads him not to a groundbreaking theory on time and space but to the hidden bureaucracy on Anarres which creates an illusory freedom of choice:

[E]very emergency, every labor draft even, tends to leave behind it an increment of bureaucratic machinery within PDC, and a kind of rigidity... [W]e're ashamed to say we've refused a posting. That the social conscience completely dominates the individual conscience...

We don't cooperate - we obey. We fear being outcast, being called lazy, dysfunctional, egoizing ... We've made laws, laws of conventional behavior, built walls all around ourselves, and we can't see them, because they're part of our thinking (Le Guin, 1975, pp. 264-265).

If we refer to Stillman's reading of Anarres as the eco-friendly utopia seems to ignore the hidden bureaucracy that is embedded in the lives of Anarresti. Whereas, from a Lacanian point of view, what is evident in the passage is that what Shevek calls social conscience is, in fact, the Freudian superego which has nothing to do with an ethical agency. Žižek points out that in the works of both Freud and Lacan, the superego represents the "same agency in its vengeful, sadistic, punishing aspect" (2007, p. 80). According to the superego's anti-ethical logic, the more the subject tries to satisfy this insatiable agency, the lesser chance the subject has meeting its demands. This is precisely Shevek's predicament. There is violence on Anarres, and this institutionalized (and internalized) violence is neither limited to a single issue nor transitory, despite what Stillman argues. The harder Shevek tries to meet the demands of (the Odonian) superego's injunctions, the more he must sacrifice. These 
repressive orthodox views also exclude individuals who do not fulfill their social obligations by labeling them as 'lazy, dysfunctional, or egoizing'. Only after losing all his possessions, Shevek can formulate his complaints (\$) in the discourse theory. He realizes that the master's discourse conceals these complaints (see Fig. II, $\$$ or the subject occupying the position of truth in the lower part of the formula). The walls concealing the consciousness of the subject are important for two reasons: it is both a symbolic and a literal wall. It should not escape our attention that the wall symbol is repeated several times in the novel, with two of them cited above. While the first instance on chapter 6, "com[ing] up against the wall" (Le Guin, 1975, pp. 130-131) shows Shevek's inability to satisfy the needs of superego, the wall Shevek is referring to in this passage is the ideological wall surrounding the subject's perception, not allowing them to see their true predicament.

Figure II: The Master's Discourse

$$
\frac{\mathrm{S}_{1}}{\$} \quad \frac{\mathrm{S}_{2}}{a}
$$

The most concrete wall; however, stands between Anarres and Urras. This is the wall that is mentioned in the first chapter of the book, surrounding the Anarresti spaceport: "There was a wall ... Like all walls it was ambiguous, two-faced. What was inside it and what was outside it depended on which side of it you were on ... It enclosed the universe, leaving Anarres outside, free" (Le Guin, 1975, pp. 1-2). As suggested in the passage, through enclosing their spaceport, the threats outside the wall are transubstantiated into a 'metaphysical' evil, and through this enclosure, Anarres protects its territory. The narrator observes the ambiguous position of Anarres's elevation of the threat outside into a mythical threat. At this point, I am indebted to Somay's insight on the Anarresti's paranoid enclosure. Somay argues that the Anarresti socio-symbolic order "has projected all the "otherness" that is inherent to itself onto the "old" world, Urras, walled itself away from it, and left no room for any "other" within" (2005, p. 240). This exclusion of "other" in the context of The Dispossessed can be explained in Žižek's terms:

The Id-Evil ... stages the most elementary 'short circuit' in the subject's relationship to the primordially missing object-cause of his desire: what 'bothers' us in the 'other' (Jew, Japanese, African, Turk...) is that he appears to entertain a privileged relationship to the object - the other either possesses the object-treasure, having snatched it away from us (which is why we don't have it), or poses a threat to our possession of the object (1994, p. 71)

Žižek's metaphor for explaining the relationship between the barred subject (\$) and the object cause of desire $(a)$ works at two levels. First, short circuit implies that there is a contact between $\$$ and $a$, since short circuit is the result of a contact of two points in a circuit that have different electric potential difference. Yet, this connection is an illusion, since this connection is 'staged' by the Id-Evil, which disguises itself as the Odonian superego in The Dispossessed. And second, as a result of this short circuit, the electric current is diverted into an unintended point in the circuit, that is "the other" in Žižek's metaphor. The current that is supposed to connect the subject to his object cause of desire, then, is stolen by the other.

SEFAD, 2021; (45): 177-190 
Combined with the master's discourse's obsession with the production of excess jouissance, the Id-Evil transforms the other to the ultimate threat. In that sense, what appears as a concrete wall surrounding the spaceport, the Anarresti wall is, in fact, a protection against the jouissance-thieves. It is in this context that Shevek flees to Urras as a political exile. Observing the conditions on Anarres, Shevek acknowledges that his search for an ideal state would require a radical transformation of his home planet. However, as we shall analyze what Shevek finds on Urras is far different from what he expected to find.

\section{Urras: On Lack and Privation}

While the objective in the previous section was to illustrate Shevek's inability to form a subject position in relation to the master's discourse of Anarres, in this section of the article I would like to demonstrate how Shevek's relationship with the Urrasti socio-symbolic order is shaped by the dynamics of infantile sexuality with reference to Lacan's early seminars.

As stated above, Shevek aims to introduce his equation of the General Temporal Theory to the Urrasti A-Io government so that a healthy relationship between two planets may flourish. Shevek's search for utopia is what we would call a belief in the utopian possibility. And this sense of utopia coincides with the Blochian sense of an ideal that "is never fully present in the here-and-now", instead it "is to be found in the Not-Yet, or the Not-Yet-Being, or In-Front-of-Us" (Freedman, 2000, p. 64). As Shevek believes in the possibility of reconciling these two ideological enemies, his longing depends on "a revolutionary reconfiguration of the world as a totality" (Freedman, 2000, p. 64). Yet, this utopian belief is problematic from a Lacanian point of view. In Critical Theory and Science Fiction, Carl Freedman (2000) also observes that for Lacan, the utopian positivity can be read "as primary narcissism, or in more strictly Lacanian terms, as pre-Imaginary plenitude" (p. 65). For both Lacan and Freud, "plenitude is primarily an illusion, and the Lacanian subject is irreducibly structured on a lack or privation that can, at best, be somewhat palliated through psychoanalytic practice but can never be radically healed" (Freedman, 2000, p. 65). If we look at the first scene where Shevek encounters the spaceship from Urras, we may see the reflections of this 'pre-Imaginary plenitude':

When first aboard the ship, in those long hours of fever and despair, he had been
distracted, sometimes pleased and sometimes irritated, by a grossly simple sensation: the
softness of the bed. Though only a bunk, its mattress gave under his weight with caressing
suppleness. It yielded to him, yielded so insistently that he was, still, always conscious of
it while falling asleep. Both the pleasure and the irritation it produced in him were
decidedly erotic ... And the design of the furniture in the officers' lounge, the smooth
plastic curves into which stubborn wood and steel had been forced, the smoothness and
delicacy of surfaces and textures: were these not also faintly, pervasively erotic? (Le
Guin, 1975, p. 15)

The reason that these everyday objects (bed, furniture, and so on) assume an erotic character (which is emphasized through "pleased ... irritated ... grossly simple sensation") cannot be explained simply as a result of Shevek's encounter with the hyper-sexualized commodities of Urrasti capitalism, where pleasure and irritation co-exist. Everything from the bed to the surfaces of the spaceship becomes a source of libidinal pleasure as if Shevek is experiencing another infantile fantasy. Since Shevek is going to his mother (planet), his voyage and the erotic experience he is going through can be read as an allegory for the infant's relationship with the mother in the Lacanian Real. The real, for Lacan, is the realm 
"without zones, subdivisions, localized highs and lows ... [it] is a sort of unrent, undifferentiated fabric, woven in such a way so as to be everywhere" (Fink, 1995, p. 24). It is the developmental stage before the infant steps into the symbolic order for Lacan. And in this pre-symbolic or pre-linguistic realm, the infant is dominated by a mixture of perceptions and feelings. Therefore, pleasure and irritation co-exist in the spaceship/womb. It would not be an over reading of the text to suggest that this scene signifies a rebirth for Shevek since in many instances in the novel, the characters mention death and rebirth as a cycle (examples include: the fourth chapter where Shevek first introduces the reincarnation is a part of the Urrasti religion; the eighth chapter where the Anarresti believes that 'the damned go to hell' (Le Guin, 1975, p. 189), meaning Urras; and its reversal on the ninth chapter where the Urrasti revolutionaries wish one another luck: 'May you get reborn on Anarres'). In that sense, Shevek the anarchist dies with his breaching the wall while Shevek the physicist is born as he progresses towards his mother planet, Urras. Thus, it is no coincidence that this prelapsarian unity with the mother is followed by feminine symbols in the following scene: "They crossed a river or estuary; the million lights of Nio Esseia, fog diffused, trembled on dark water, behind them. The road darkened, the fog thickened, the driver slowed the vehicle's pace. Its lights shone on the mist ahead as if on a wall that kept retreating before them" (Le Guin, 1975, p. 17). As Shevek is introduced to another socio-symbolic order through the spaceship/womb, his arrival to Urras is a symbolic birth surrounded by wet, humid and damp environment. Through his re/birth to a capitalist socio-symbolic order, Shevek perceives to be able to breach the wall that he was surrounded by (the vehicle's light shining through the wall of mist).

In this illusory pre-Imaginary plenitude, Shevek is also able to put both planets into perspective:

The tenderness and vitality of the colors, the mixture of rectilinear human design and powerful, proliferate natural contours, the variety and harmony of the elements, gave an impression of complex wholeness such as he had never seen.

Compared to this, every scene Anarres could offer, even the Plain of Abbenay and the gorges of the Ne Theras, was meager: barren, arid, and inchoate. This is what a world is supposed to look like, Shevek thought. (Le Guin, 1975, pp. 52-53)

"The tenderness and vitality" of the landscape combining the natural elements with that of cultural draw a stark black and white contrast with the barren landscape of Anarres. But, as in the first passage in the spaceship, this "impression of wholeness" is also an illusion because of the primary narcissism. Shevek, at this point, is unable to acknowledge that the hysteric's discourse he assumes conceals the truth ( $a$, surplus jouissance) that all desire rests on a lack that cannot be satisfied.

On Anarres, 'nothing he did was understood', his works and theories passed unacknowledged or were published under the name of another physicist who exploited his labor; Shevek could not exist as an independent actor. Although Shevek achieves everything he craved on Anarres in this new environment - fame, a respected position at the university in A-Io- yet he feels discontent. Shortly after paying a visit to the grave of the revolutionary figure Odo who is 'the mother' of all anarchists, on chapter 3, he feels that he does not belong to Urras either:

He was alone, here, because he came from a self-exiled society. He had always been alone on his own world because he had exiled himself from his society. The Settlers [of Anarres] 
had taken one step away. He had taken two. He stood by himself, because he had taken the metaphysical risk.

And he had been fool enough to think that he might serve to bring together two worlds to which he did not belong. (Le Guin, 1975, p. 72)

His disposition, although not explicitly stated in the novel, may be a reaction to the inscription he reads in Odo's tombstone: "To be whole is to be part; / true voyage is return" (Le Guin, 1975, p. 68). Shevek, an outsider who took the voyage to return (to his ancestral planet) cannot be a part of this brand new social order; nor can he be a part of the anarchist social order since he cannot take the voyage to return. His belief in the utopian possibility is shaken further when he realizes that the capitalist social order is not any different from the enclosing dystopia he ran away from.

As Shevek steps out of his safe environment at the university to meet the Urrasti revolutionaries, he is unable to identify the beautiful Urrasti city, Nio Esseia. The shining city with its "massive walls of stone and glass ... [and] electric light" (Le Guin, 1975, p. 16) which greets him in his arrival to the planet leaves its place to an unknown territory in the slums: "The lampposts were there, but the lights were not turned on, or were broken. Yellow gleams slitted from around shuttered windows here and there" (Le Guin, 1975, p. 233). Here, in the slums, Shevek sees a man lying in the gutter: "His coat bunched up over his head, lying in the rain, asleep, sick, dead. Shevek stared at him with horror, and at the others who walked past without looking" (Le Guin, 1975, p. 234). These brief episodes do much more than giving Shevek a character motivation to defend the rights of the victims of Urrasti capitalism. These also illustrate that despite its ability to meet Shevek's needs, the capitalist socio-symbolic order is no different than that of Anarresti anarchism. The only difference, in the case of Anarres, is the material lack that has caused a rigid master-slave dialectic whereas on Urras it is the economic violence that is inherent in the system itself. The master's discourse is the dominant discourse in both socio-symbolic orders.

Stuck in the hysteric's discourse that is endlessly producing new narratives (see Fig. IV, the lower part of the formula, $S_{2}$ ) that do not solve the fundamental lack ( $a$, again the lower part of the formula holding the position of truth) but engenders more irritation (\$), Shevek is left in a position where he has to formulate a new solution to his impasse. When the divided subject's (Shevek, \$) interrogation of the master signifier (the Urrasti sociosymbolic order in this case) does not allow him to produce knowledge, Shevek confronts what Lacan would call "the symbolic lack of an imaginary object" (Evans, 2006, p. 23), i.e. phallus. Thinking in terms of infantile sexuality, this impasse is the unanswerable question of the infant to his mother: Che vuoi? or 'What do you want from me?'. The infant's answer is to try to satisfy the mother by identifying with the imaginary phallus (Evans, 2006, p. 121). Thus, it is no coincidence that after falling out with the academic institutions, he tries to embody what he thinks the mother lacks. In the eyes of the Urrasti rebels, Shevek becomes "the idea of anarchism, made flesh" (Le Guin, 1975, p. 237).

As Shevek slowly realizes that there is no return to the mother and a prelapsarian plenitude, his actions on Urras mirror the Oedipus complex in the Lacanian sense. As Evans shows, for Lacan, the Oedipus complex has three stages: in the first stage, "the child perceives that the mother desires something beyond the child himself - namely, the imaginary phallus- and then tries to be the phallus for the mother" (2006, p. 23). Thus, it is no coincidence that after his disillusionment with the Urrasti society, Shevek joins the 
revolutionary group to defend the rights of the economically unprivileged on Urras (Le Guin, 1975, p. 239). Yet, his attempt at assuming the imaginary phallus is disrupted when the Urrasti government disrupts the peaceful demonstration with excessive force, killing hundreds in the streets (Le Guin, 1975, pp. 242-246). This is what Lacan calls the intervention of the imaginary father in separating the child from the mother through incest taboo in his seminar on frustration and privation.

\section{Dwelling the Threshold: The Name-of-the-Father}

Reminiscent of the unrest of the late 1960s, the last scene marks a radical difference in Shevek's character. At the end of Chapter 11, he is forced to acknowledge the shortcomings of his subject position. The very thing that he thought he desired $\left(S_{2}\right.$, knowledge, as shown in Fig IV) becomes futile when he is left alone with a dying Urrasti worker for three days. He accepts that his aim of bringing the two societies by introducing his equation was in vain: "Weigh [my equation] in the balance with the freedom of one single human spirit ... [W] hich will weigh heavier? Can you tell? I cannot" (Le Guin, 1975, p. 282).

Figure IV: The Hysteric's Discourse

$\frac{\$}{a} \quad \frac{S_{1}}{S_{2}}$

In Chapter 13, Shevek returns to his home planet in a state of uncertainty and resignation. He is uncertain of his safety because, as his birth mother Rulag said in the previous chapter, once leaving the planet, Shevek would jeopardize his way back home (Le Guin, 1975, p. 287). And he feels resignation because his every attempt at forming a subject position or realizing an ideal state has met with failure. Khouri reads this resignation scene as Le Guin's failure of "dramatiz[ing] the relationships between power and the utopian possibility" (1980, p. 50). For Khouri, it is the perception of the individual's being "incapable of exercising any power over material reality" (1980, p. 53). Khouri argues that the novel "closes on an impossible transformation, on an inaccessible utopia" (1980, p. 53). However, perhaps the most optimistic passage in the novel comes at the very end with the arrival of an alien named Ketho who is a Hainishman. The Hainish are the oldest civilization in Le Guin's fictional universe, and their race has established many political regimes. Although they are an ancient civilization, Ketho states: "We have histories of hundreds of those millennia. We have tried everything. Anarchism, with the rest. But I have not tried it" (Le Guin, 1975, p. 310). Accepting the dangers of stepping into a foreign (and possibly hostile) land, Ketho and Shevek wait for the landing. Even though the novel does not reveal their fate, the true revolutionary potential of The Dispossessed lies in this scene. Shevek, after all his attempts, is able to break down the wall, not through his equation (i.e. $S_{2}$ or knowledge) but through inverting the master's discourse. Somay is right to point out that Ketho acts as the name-ofthe-father, separating Shevek from the mother/child binary (2005, p. 243). In Lacanian terms, "name-of-the-father" or "no-of-the-father" (nom-du-père/non-du-père in French) designates that language enters into the infant's psychological constitution always in the form of a prohibition (Somay, 2005, p. 246). However, this "father" should not be confused with

SEFAD, 2021; (45): 177-190 
Freud's father-imago or the biological father. It can be any element in the symbolic order which plays legislative and prohibitive function (Evans, 2006, p. 122).

Figure II: The Master's Discourse

Figure V: The Analyst's Discourse

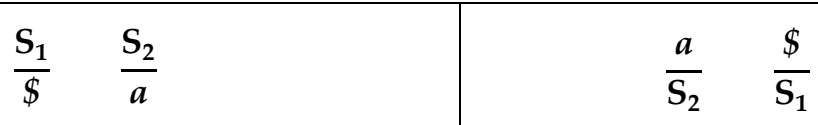

Only through the arrival of Ketho can Shevek be saved from his obsession with the always absent mother. My contribution to the discussion of Ketho/Shevek relationship, from a late-Lacanian perspective, is to introduce Lacan's discourse theory since Lacan himself left "name-of-the-father" concept as early as his 1957 seminars (Evans, 2006, p. 122). From the perspective of the discourse theory, not only did Ketho change Shevek but also Shevek reversed the original schema of the master's discourse in Fig. II by becoming the object cause of desire (a) for Ketho. In the discourse of the analyst, as seen in Fig. V, the analyst holds the position of the agent, while the analysand becomes the other. The agent always hides the knowledge ( $S_{2}$, the lower part of the formula), while the other asks the question: "Che vuoi? What do you want?" This is precisely at what Shevek aimed initially. Anarres, as cited above, has a close political organization which is strictly regulated to protect itself from the outside threats. By introducing a peaceful alien who is in search of his personal utopia to the Anarresti order, Shevek achieves his initial aim of "shak[ing] up things ... [and] mak[ing] people ask questions" (Le Guin, 1975, p. 309). This move is revolutionary at another level as well. The analyst's discourse as seen in Fig. $\mathrm{V}$ is an inversion of the master's discourse.

\section{CONCLUSION}

In The Dispossessed: An Ambiguous Utopia, Le Guin aims to undermine the stability of both social and economic structures of capitalism and anarchism by engaging in a critique of their utopian agendas. On an individual level, the novel is about one man's almost impossible search of a place for himself in a sustainable social order. Shevek's journey from the anarchist social order to the capitalist planet, Urras, serves as an allegory for how the socio-symbolic order shapes the individual subject. At the same time, on a larger scale, The Dispossessed engages with the political implications of this search for the ideal. The importance of a Lacanian analysis lies in its insistence on the discursive play of signifiers in shaping the individual subject. As I illustrated, the individual search cannot be separated from the revolutionary politics of the novel because when one man's search for utopia ends, the other one's journey begins. While Anarres is ecologically sustainable as Stillman argues, it is not the optimum condition for a utopia since the problems that the individual subjects must face do not necessarily relate to ecological concerns. Likewise, The Dispossessed does not have a moralistic or regressive aspect to it as Khouri argues. While Anarres is unable to provide a healthy alternative to the capitalist mode of production, its ideological opposite is equally not a utopia. While their opposite qualities are only on the surface, their discourse is the same, as illustrated above. What, one might wonder, would a psychoanalytic approach to The Dispossessed contribute to our way of understanding the text. A Lacanian perspective provides an insight beyond the political aspect of the novel because regardless of the political/economic organization, whether it is anarchism or capitalism, the Lacanian 
discourse theory shows that both socio-symbolic orders can be seen as two sides of the same coin since both assume the master's discourse. In Le Guin's ambiguous utopia, the roadmap to the ideal state is provided with a Lacanian twist which includes the subversion of the master's discourse at the end.

\section{Article Information}

Ethics Committee Approval:

Informed Consent:

Financial Support:

Conflict of Interest:

Copyrights:
Exempt from the Ethics Committee Decision.

No participant

No financial support from any institution or project.

No conflict of interest.

No material subject to copyright is included. 


\section{BIBLIOGRAPHY}

Bianchi, P. (2012). From representation to class struggle. S: Journal of the Van Eyck Circle for Lacanian Ideology Critique, 5, 114-126.

Evans, D. (2006). An introductory dictionary of lacanian psychoanalysis. London and New York: Routledge.

Fink, B. (1995). The lacanian subject: Between language and jouissance. New Jersey: Princeton University Press.

Freedman, C. (2000). Critical theory and science fiction. Middletown: Wesleyan University Press.

Khouri, N. (1980). The dialectics of power: Utopia in the science fiction of Le Guin, Jeury, and Piercy. Science Fiction Studies, 7(1), 49-60. Retrieved from www.jstor.org/stable/4239310

Lacan, J. (1999). To Jakobson. In J. Lacan, The seminar of Jacques Lacan, book xx, on feminine sexuality: The limits of love and knowledge. (B. Fink, Trans.) (pp. 14-25). New York: W. W. Norton. (Original work published 1975)

Lacan, J. (2007). The seminar of Jacques Lacan, book xvii, the other side of psychoanalysis. (R. Grigg, Trans.) New York: W. W. Norton. (Original work published 1991)

Le Guin, U. K. (1975). The dispossessed: An ambiguous utopia. New York: Avon.

Somay, B. (2005). From ambiguity to self-reflexivity: Revolutionizing fantasy space. In L. Davis, \& P. G. Stillman (Eds.), The new utopian politics of Ursula K. Le Guin's the dispossessed (pp. 233-247). Lanham: Lexington.

Stillman, P. G. (2005). The dispossessed as ecological political theory. In L. Davis, \& P. G. Stillman (Eds.), The new utopian politics of Ursula K. Le Guin's the dispossessed (pp. 55-73). Lanham: Lexington.

Žižek, S. (1994). The metastases of enjoyment: Six essays on woman and causality. New York: Verso.

Žižek, S. (2007). How to read Lacan. New York: W. W. Norton. 